\title{
Effect of Cultivar and Explants Type on Tissue Culture Regeneration of Three Nigerian Cultivars of Tomatoes
}

\author{
Ajenifujah-Solebo S. O. A. ${ }^{1}$, Isu N. A. ${ }^{2}$, Olorode O. ${ }^{2} \&$ Ingelbrecht I. ${ }^{3}$ \\ ${ }^{1}$ National Biotechnology Development Agency, Abuja, Nigeria \\ ${ }^{2}$ Biological Sciences Department, University of Abuja, Abuja, Nigeria \\ ${ }^{3}$ International Institute of Tropical Agriculture, Ibadan, Oyo State, Nigeria \\ * Current address: Department of Plant Biotechnology and Genetics, Gent University, Belgium \\ Correspondence: Ajenifujah-Solebo S. O. A., National Biotechnology Development Agency, Abuja, Nigeria. Tel: \\ 234-809-824-4979. E-mail: adetoyin73@yahoo.com
}

Received: January 4, 2013 Accepted: April 20, 2013 Online Published: May 5, 2013

doi:10.5539/sar.v2n3p58 URL: http://dx.doi.org/10.5539/sar.v2n3p58

\begin{abstract}
In order to assess the suitable explant(s) for in-vitro regeneration of three local cultivars of Nigerian tomatoes, Ibadan local (IbL), Ife and JM94/46, cotyledon, hypocotyls and radicle explants were cultured in shoot regeneration medium consisting of MS containing $30 \mathrm{~g} \mathrm{~L}^{-1}$ sucrose and $8 \mathrm{~g} \mathrm{~L}^{-1}$ agar with no exogenous plant growth hormones. Forty-five of each explant type was cultured on the medium in triplicate experiments and results showed varied percentage survival and shooting for the various explants. Hypocotyl explants had the highest percentage of shooting explants at $13.3 \%$ for IbL; $6.67 \%$ for Ife and $20 \%$ in JM94/46. IbL cotyledon explants had $4.44 \%$ of shooting explants with no shoots recorded in Ife and JM94/46 cotyledon explants. IbL radicle explants had 2.22\% shooting explants and no shoots recorded in Ife and JM94/46. Student Neuman Keuls (SNK) statistical analysis of cultivar-media interaction showed there was no significant difference $(\mathrm{P}>0.05)$ among the three cultivars in number of calli and shooting calli. There was however significant difference among the cultivars in the number of shoots recorded. SNK values for explants-media interaction showed that cotyledon and radicle explants were significantly different $(\mathrm{P}<0.05)$ from hypocotyl explants in the number of shoots produced.
\end{abstract}

Keywords: Solanum lycopersicon, Nigerian, cultivar, cotyledon, hypocotyl, radicle

\section{Introduction}

Tomato (Solanum lycopersicon L.) belongs to the family Solanaceae and is the world's most widely cultivated vegetable (Villarael, 1980) with an estimated global production of over 159,023,383 tons (FAOSTAT, 2011). It is a fleshy berry, globular to oblate, smooth or furrowed about $2-15 \mathrm{~cm}$ in diameter, usually red when ripe, sometimes pink, orange or yellow and many seeded (Van der Vossen \& Nono-Womdim, 2004). Tomato is rich in vitamins A and C and fibre; it is also cholesterol-free (Hobson \& Davies, 1971) and contains approximately $20-50 \mathrm{mg}$ lycopene/100 $\mathrm{g}$ of fruit weight (Kalloo, 1991). Tomato fruits are a significant source of nutrition for substantial portions of the world's human population because this vegetable crop is widely cultivated and consumed extensively as both a fresh vegetable and concentrated processed products. A single small tomato is sufficient to supply about a quarter of the vitamins A and C recommended for humans to consume daily (Hamner \& Maynard, 1942; Beecher, 1998).

Nigeria is the largest producer of tomatoes in tropical Africa, accounting for an annual production of 1,504,670 tons (FAOSTAT, 2011). Nigeria's production is about 1.5 million tons out of the estimated annual production of 16.55 million tons in Africa (FAOSTAT, 2011). In Nigeria alone, annual total area of one million hectares is reportedly used for its cultivation (Anonymous, 1989; Bodunde, Erinle, Eruotor, \& Amans, 1993). The use of tomato is about 18 percent of the average daily consumption of vegetables in Nigeria (Olayide, Olatunbosun, Idusogie, \& Abiagom, 1972). A large volume of the tomatoes consumed in Nigeria are usually transported over long distances from the Northern part of the country to other parts. In Nigeria, as in most other developing countries, efficient storage, packaging, transport and handling techniques are practically non-existent for perishable crops (Babalola, Makinde, Omonona, \& Oyekanmi, 2010) resulting in considerable loss of produce. 
Local cultivars of tomatoes in Nigeria suffer from a myriad of problems ranging from post harvest losses due to biochemical processes and the humid climate; diseases caused by bacteria, fungi, viruses and nematodes. The introduction of genes that confer these qualities to commercial cultivars by conventional breeding techniques often encounters serious difficulties due to high incompatibility barriers to hybridization (Kaul, 1991). To overcome these problems certain more recent approaches of gene manipulation might be required. Therefore the application of biotechnology to bring about a number of improvements may be necessary in the locally cultivated cultivars such as longer shelf-life, resistance to biotic and abiotic stresses, nutrient enhancement, higher soluble solids, etc.

The development of protocols for in-vitro selection can provide new advances for the production of stress tolerant cultivars (Bhatia, Ashwath, Senaratna, \& Midmore, 2004). In-vitro regeneration of cultivated tomato (Solanum lycopersicon) has been a subject of research because of the commercial value of the crop and its potential of amenability to further improvement through genetic engineering strategy (Evans, 1989). Yet, studies on in-vitro regeneration of local cultivars of tomato in Nigeria have not been extensive. An efficient tissue culture protocol is an essential pre-requisite for harnessing the advantage of cell and tissue culture for genetic improvement. Efficient plantlet regeneration in tomato was reported from meristems (Mirghis, Mirghis, \& Lacatus, 1995), leaf (Padmanabhan, Paddock, \& Sharp, 1974; Behki \& Lesley, 1976; Kartha, Gamborg, Shyluk, \& Constable, 1976; Ajenifujah-Solebo, Isu, Olorode, Ingelbrecht, \& Abiade, 2012), stems, anthers (Zamir, Jones, \& Kedar, 1980) and hypocotyls (Ohki, Bigot, \& Mouseau, 1978).

This study is therefore to assess the in-vitro regeneration response of various explant types of three local cultivars of tomatoes, Ibadan local, Ife and JM94/46 which are farmer preferred varieties in the south-western part of Nigeria obtained from the National Institute for Horticultural Research and Training (NIHORT). These cultivars are reported to be resistant to certain diseases and relatively high yielding (Badra, Denton, \& Anyim, 1984; Anno-Nyako \& Ladunni, 1984).

\section{Materials and Methods}

Seeds of three local cultivars of tomatoes namely Ibadan local, Ife and JM94/46 were obtained from the National Institute for Horticultural Research and Training (NIHORT), Ibadan, Nigeria. Cotyledon, hypocotyls and radicle explants were taken from each of the cultivars and used for in-vitro regeneration studies. Fifteen pieces of the different explant types from each cultivar were cultured on medium in petri-dish and set in complete randomized design (CRD) with three replications. Data was pooled from the experiments and subjected to analysis of variance (ANOVA).

\subsection{In-vitro Seed Establishment}

The tomato seeds were surface sterilized with $\mathrm{NaOCl}(3.5 \% \mathrm{v} / \mathrm{v})$ containing a drop of tween 20 for 20 min without an ethanol treatment. The seeds were then rinsed with sterile distilled water at least three times. About 50-100 ml of MS (Moorashige \& Skoog, 1962) medium consisting of $30 \mathrm{~g} \mathrm{~L}^{-1}$ sucrose and $8 \mathrm{~g} \mathrm{~L}^{-1}$ agar gel without any growth hormones and $\mathrm{pH}$ adjusted to 5.8 was filled into culture bottles and sterilized by autoclaving at $121{ }^{\circ} \mathrm{C}$ at $15 \mathrm{psi}$ for $15 \mathrm{~min}$. Efficiency of sterilization was ascertained using Bowie Dick auto clave tape which changed from blue to white. The medium was allowed to cool and solidify prior to seed inoculation. Each culture jar was inoculated with ten surface sterilised seeds and were placed in the dark at $25 \pm 2{ }^{\circ} \mathrm{C}$ for $3-5 \mathrm{~d}$ to germinate and then transferred to growth conditions of $16 \mathrm{~h}$ photoperiod with light intensity of 1500 lux for 7-10 $\mathrm{d}$ at the same temperature.

\subsection{In-vitro Regeneration Through Direct Shoot Organogenesis}

Cotyledon $\left(5 \times 5 \mathrm{~mm}^{2}\right)$, hypocotyls and radicle $(5-6 \mathrm{~mm})$ explants from 10-13 d old in-vitro tomato seedlings of Ibadan local (IbL), Ife and JM94/46 cultivars were excised under asceptic conditions and were cultured on shoot regeneration medium (SRM) consisting of MS with $30 \mathrm{~g} \mathrm{~L}^{-1}$ sucrose and $8 \mathrm{~g} \mathrm{~L}^{-1}$ agar gel. After about 3-4 weeks in the shoot regeneration medium, regenerated shoots were sub-cultured into the rooting medium (RM) consisting of MS with $15 \mathrm{~g} \mathrm{~L}^{-1}$ sucrose and $8 \mathrm{~g} \mathrm{~L}^{-1}$ agar gel and $0.1 \mathrm{mg} \mathrm{L}^{-1} \mathrm{NAA}$. After $10 \mathrm{~d}$ in RM, rooted plants were taken to the screen house for hardening.

\subsection{Ex-situ Seedling Establishment}

Rooted plants were transferred to hardening medium consisting of coconut fibre pellets (peet) which were soaked in water for about $3 \mathrm{~h}$ to loosen up and vermiculite was added to make the medium sturdy enough to keep the plants upright. The mixture was poured into polythene bags and the rooting plants were transferred into the medium. They were kept in humidity chamber for 2 weeks before planting in soil in pots for another 2 weeks, still under humidity chamber and gradually acclimatized in the screen house environment. 


\subsection{Statistical Analysis of Regeneration Data}

Data was pooled from the regeneration experiments and subjected to analysis of variance (ANOVA) using the general linear model (GLM) procedure of Statistical Analysis Software (SAS)-(SAS Institute, Cary, NC) (Version 8.2, 2001). Least significant difference (LSD) test was based on Student Neuman Keuls' (SNK) procedure after a significant F-test in the analysis of variance.

\section{Result}

\subsection{Direct Shoot Regeneration}

Seeds of cultivar JM94/46 germinated 3 days after planting (d.a.p.) while Ife and IbL germinated about 5 d.a.p. For cultivar IbL, only $4.44 \%$ of cotyledon explants developed shoots; while no shoot was recorded for Ife and JM94/46 cultivars. IbL survival rate on SRM was 84.44\% (Table 1). Only 2 from the surviving thirty-eight cotyledon explants from the initial 45 produced shoots but the shoots produced were not transferred as individual shoots. The rate of survival of Ife and JM94/46 cotyledon explants on the medium was $93.33 \%$ and $71.11 \%$ respectively, but no shoots were produced.

Table 1. Regeneration of cotyledon explants of the three tomato cultivars

\begin{tabular}{cccccccc}
\hline Cultivar & $\begin{array}{c}\text { No. of } \\
\text { explant }\end{array}$ & $\begin{array}{c}\text { Surviving } \\
\text { Explants }\end{array}$ & \% survival & $\begin{array}{c}\text { Shooting } \\
\text { explant }\end{array}$ & $\begin{array}{c}\% \\
\text { shooting } \\
\text { explant }\end{array}$ & $\begin{array}{c}\text { No of } \\
\text { shoots }\end{array}$ & $\begin{array}{c}\text { Average } \\
\text { shoot/ } \\
\text { explant }\end{array}$ \\
\hline IbL & 45 & 38 & 84.44 & 2 & 4.44 & 0 & 0 \\
Ife & 45 & 42 & 93.33 & 0 & 0 & 0 & 0 \\
JM94/46 & 45 & 32 & 71.11 & 0 & 0 & 0 & 0 \\
\hline
\end{tabular}

From the 45 hypocotyl explants cultured in triplicate experiments for IbL, Ife and JM94/46 cultivars, only 6,3 and 9 explants produced shoots respectively (Table 2). JM94/46 had the highest number of shooting hypocotyl explants of 9 from 28 surviving explants. Percentage shooting explants was 13.3, 6.67 and 20 respectively for IbL, Ife and JM94/46. No shoots were produced from Ife; average shoots/explant for IbL and JM94/46 was 2.17 and 2.89 respectively.

Table 2. Regeneration of hypocotyl explants of the three tomato cultivars

\begin{tabular}{cccccccc}
\hline Cultivar & $\begin{array}{c}\text { No. of } \\
\text { explant }\end{array}$ & $\begin{array}{c}\text { Surviving } \\
\text { Explants }\end{array}$ & \% survival & $\begin{array}{c}\text { Shooting } \\
\text { explant }\end{array}$ & $\begin{array}{c}\% \\
\text { shooting } \\
\text { explant }\end{array}$ & $\begin{array}{c}\text { No. of } \\
\text { shoots }\end{array}$ & $\begin{array}{c}\text { Average } \\
\text { shoot/ } \\
\text { explant }\end{array}$ \\
\hline IbL & 45 & 26 & 57.78 & 6 & 13.33 & 13 & 2.17 \\
Ife & 45 & 27 & 60 & 3 & 6.67 & 0 & 0 \\
JM94/46 & 45 & 28 & 62.22 & 9 & 20 & 26 & 2.89 \\
\hline
\end{tabular}

For radicle explants, only IbL produced one shoot; while Ife and JM94/46 cultivars did not produce any shoots. Percentage survival of radicle explants of the cultivars was 57.7, 48.89 and 71.11 for IbL, Ife and JM94/46 cultivars respectively (Table 3 ).

Table 3. Regeneration of radicle explants of the three tomato cultivars

\begin{tabular}{cccccccc}
\hline Cultivar & $\begin{array}{c}\text { No. of } \\
\text { explant }\end{array}$ & $\begin{array}{c}\text { Surviving } \\
\text { Explants }\end{array}$ & \% survival & $\begin{array}{c}\text { Shooting } \\
\text { explant }\end{array}$ & $\begin{array}{c}\% \\
\text { shooting } \\
\text { explant }\end{array}$ & $\begin{array}{c}\text { No of } \\
\text { shoots }\end{array}$ & $\begin{array}{c}\text { Average } \\
\text { shoot/ } \\
\text { explant }\end{array}$ \\
\hline IbL & 45 & 26 & 57.78 & 1 & 2.22 & 1 & 0.026 \\
Ife & 45 & 22 & 48.89 & 0 & 0 & 0 & 0 \\
JM94/46 & 45 & 32 & 71.11 & 0 & 0 & 0 & 0 \\
\hline
\end{tabular}




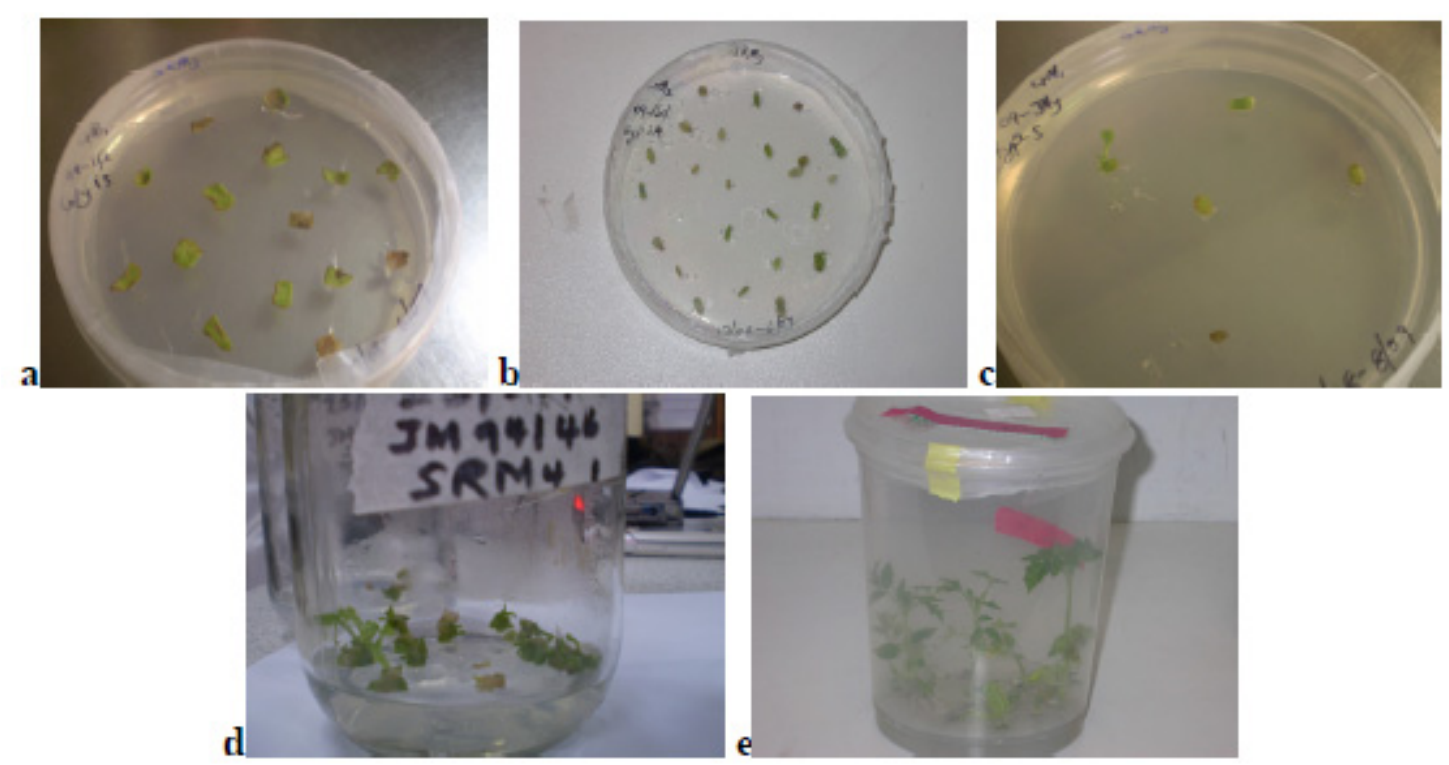

Figure 1. (a) Cotyledon explants (3 wks); (b) Hypocotyl explants (3 wks); Radicle explants (3 wks); (d) Shooting hypocotyl explants (6 wks); (e) Rooting seedlings from hypocotyl explant (8-10 wks)

Student Neuman Keuls (SNK) values for cultivar-media interaction showed that there was no significant difference at $\mathrm{P}>0.05$ in the response of the cultivars for number of calli and shooting calli (Table 4); there was however significant difference $(\mathrm{P}<0.05)$ between Ife and JM94/46 in the number of shoots produced. SNK values for explant-media interaction indicated that hypocotyl and radicle explants response were not significantly different $(\mathrm{P}>0.05)$ for number of calli formed, but was significantly different from cotyledon. Cotyledon and radicle explants response in the medium for shooting calli and number of shoots produced were not significantly different $(\mathrm{P}>0.05)$ while hypocotyls response was significantly different (Table 5).

Table 4. Mean values of SNK test for cultivars-media interaction (cultivar* media)

\begin{tabular}{llll}
\hline Cultivar & IbL & Ife & JM94/46 \\
\hline No calli & $0.667 \mathrm{a}$ & $0.674 \mathrm{a}$ & $0.681 \mathrm{a}$ \\
Shoot calli & $0.067 \mathrm{a}$ & $0.022 \mathrm{a}$ & $0.067 \mathrm{a}$ \\
Shoots & $0.104 \mathrm{ab}$ & $0.000 \mathrm{~b}$ & $0.193 \mathrm{a}$ \\
\hline
\end{tabular}

Mean values with same letters on the same row are not significantly different at $\alpha=0.05$.

Table 5. Mean values of SNK test for explants-media interaction (explants * media)

\begin{tabular}{llll}
\hline Explants & Cotyledon & Hypocotyl & Radicle \\
\hline No calli & $0.8296 \mathrm{a}$ & $0.600 \mathrm{~b}$ & $0.593 \mathrm{~b}$ \\
Shoot calli & $0.0148 \mathrm{~b}$ & $0.133 \mathrm{a}$ & $0.0074 \mathrm{~b}$ \\
Shoots & $0.000 \mathrm{~b}$ & $0.289 \mathrm{a}$ & $0.0074 \mathrm{~b}$ \\
\hline
\end{tabular}

Mean values with same letters on the same row are not significantly different at $\alpha=0.05$.

The Least Significant Difference (LSD) values (Table 6) indicates that there was significant difference $(\mathrm{P}<0.05)$ in the survival rate of calli, shooting explants and shoots in SRM. There was significant difference $(\mathrm{P}<0.05)$ among the cultivars for no. of shoots produced; while there was no significant difference $(\mathrm{P}>0.05)$ in calli formation and shooting explants among the three cultivars. There was significant difference $(\mathrm{P}<0.05)$ among the explants in calli formation, shooting explant and shoot formation in the medium. 
Table 6. LSD Values for cultivars and explants in SRM at $\mathrm{P} \leq 0.05$

\begin{tabular}{lllll}
\hline \multicolumn{4}{c}{ LSD Values } \\
\cline { 2 - 5 } Parameter & Survive & Cultivar & Explant \\
\hline Calli & 0.0001 & 0.9654 & $<0.0001$ \\
Shoot explant & $<0.0001$ & 0.1459 & $<0.0001$ \\
Shoot & $<0.0001$ & 0.0071 & $<0.0001$ \\
\hline
\end{tabular}

$P$ values $\leq 0.05$ are not significantly different.

\subsection{Rooting and Hardening of Regenerated Shoots}

Elongated shoots from IbL and JM94/46 hypocotyl explants were transferred to rooting medium (RM) after 4-6 weeks in SRM. Rooted plants were transferred to hardening medium for 3-4 weeks comprising of 2 weeks in peet and vermiculite; and then planted in soil pots for another 2 weeks under controlled humidity conditions.

\section{Discussions}

Due to the lack of information on explants to use for regeneration in local tomato cultivars, different parts (cotyledon, hypocotyl and radicle) of tomato seedlings were used as explants in shoot regeneration media (SRM) without exogenous growth hormones to determine the most suitable to these local cultivars. Both roots and cotyledons of young seedlings actively produce PGRs involved in the control of organogenesis (Hicks, 1994). Pozueta-Romero, Houlne, Canas, Schantz, and Chamarro (2001) reported the successful regeneration of tomato and bell peppers on medium without exogenous growth hormones from decapitated explants with radicle, hypocotyl and with or without cotyledon explants.

\subsection{Direct Shoot Regeneration}

Various researchers have reported the successful use of different explants; hypocotyl (Davis, Breiland, Frear \& Secor, 1994; Venkatachalam, Geetha, Priya, Rajaseger, \& Jayabalan, 2000); cotyledon (Costa, Nogueira, Otoni \& Brommonschenkel, 2000; Sun, Uchii, Watanabe, \& Ezura, 2006); radicle, hypocotyls and cotyledon (Pozueta-Romero et al., 2001). The results of this study did not however support the literature as only hypocotyl explants of IbL and JM cultivars responded in SRM without growth hormones and the response of the three different explants of IbL to the medium were significantly different at $\mathrm{P}>0.05$. Average shoots/explant from hypocotyls explants in IbL and JM94/46 in SRM were 2.17 and 2.89 respectively. Only few of the surviving explants produced shoots. These results are comparable to that reported by Pozueta-Romero et al. (2001) of 2.8 shoots per explant in tomato cultivar Rutgers in similar medium with no exogenous growth hormones. JM94/46 hypocotyl explants therefore had the best response in SRM followed by IbL. Cotyledon and radicle explants showed poor response in the medium. Plastira and Perdikaris (1997) reported differential regeneration frequency of various explants in the order hypocotyls > cotyledon > leaf. Gunnay and Rao (1980) also demonstrated preferential regeneration from hypocotyls plants than cotyledon explants; which supports the results of these experiments. Hypocotyl explants from the three cultivars responded at varying degrees in SRM. The superiority of hypocotyls explant derived callus in terms of plantlet regeneration corroborates the findings of Locky (1983).

\subsection{Root Induction}

Rooting medium according to Sun et al. (2006) with no exogenous plant growth hormone (PGH) was adopted, which is in line with report by Mensuali-Sodi et al. (1995) that tomato does not usually require any (PGR) for rooting. The cultures however did not produce roots after three weeks in the rooting medium. The modification of the rooting medium by the addition of $0.1 \mathrm{mg} \mathrm{L}^{-1}$ of NAA (auxin) as reported by Davis et al. (1994) resulted in the development of roots which was observed after 8-10 days. Compton and Veilleux (1991) also reported the use of NAA at concentrations of $0.02 \mathrm{mg} \mathrm{L}^{-1}$ to induce rooting from leaf and hypocotyl explants.

\section{Conclusions}

Results of these experiments show the influence and importance of growth regulators on the number of shoots regenerated from tomato explants (cotyledons, hypocotyls and radicles). Although plants have endogenous growth hormones, they are sometimes required to be supplemented under in-vitro conditions to obtain optimal results. This is corroborated by the reports of Jozef, Zuzana, and Zuzana (2004) that the addition of growth regulators in media enhanced the number of shoots regenerated from tomato cotyledons and hypocotyls. The in-vitro morphogenic responses of in-vitro cultured plant tissues are therefore affected by the different 
components of the culture media, especially by concentration of growth hormones. These responses are also dependent on cultivar and explants types. The addition of plant growth hormones to the shoot regeneration medium could therefore enhance shoot regeneration in these cultivars and explants. Other experiments with the same cultivars using cotyledon explants in shoot regeneration medium supplemented with $0.1 \mathrm{mg} \mathrm{L}^{-1}$ IAA and 1 $\mathrm{mg} \mathrm{L}^{-1}$ zeatin (Ajenifujah-Solebo et al., 2012) gave higher percentage of shooting (64-97\%) from the three cultivars.

\section{Acknowledgements}

The authors acknowledge the funding support of the National Biotechnology Development Agency-Post Basic Science and Technology Education World Bank Project (NABDA/STEP-B World Bank Project), Abuja, Nigeria; the use of facilities at the International Institute of Tropical Agriculture (IITA), Ibadan, Nigeria and the assistance of Mrs. Olayemi Oluwasoga with the statistical analysis of the data.

\section{References}

Ajenifujah-Solebo, S. O. A., Isu, N. A., Olorode, O., Ingelbrecht, I., \& Abiade, O. O. (2012). Tissue culture regeneration of three Nigerian cultivars of tomatoes. African Journal of Plant Science, 6(14), 370-375.

Anno-Nyako, F., \& Ladunni, A. (1984). Evaluation of tomato germplasm under field conditions for reaction to tomato virus disease. National Institute for Horticultural Research and Training (NIHORT) Annual Report pp. 23-24.

Anon. (1989). Fertilizer use and management practices for crops in Nigeria. Series No 2. Federal Ministry of Agriculture, Water resources and Rural development, Lagos. p. 163.

Babalola, D. A., Makinde, Y. O., Omonona, B. T., \& Oyekanmi, M. O. (2010). Determinants of post harvest losses in tomato production: a case study of Imeko-Afon local government area of Ogun state. Acta satech, $3(2), 14-18$.

Badra, T., Denton, O., \& Anyim, O. (1984). Tomato germplasm evaluation. National Institute for Horticultural Research and Training (NIHORT) Annual Report, pp. 22-23.

Beecher, G. R. (1998). Nutrient Content of tomatoes and tomato products. Proc. Soc. Exp. Biol. and Med., 218(2), 98-100.

Behki, R. M., \& Lesley, S. M. (1976). In-vitro plant regeneration from leaf explants of Lycopersicum esculentum (tomato). Canadian J. Bot., 54, 2409-2414. http://dx.doi.org/10.1139/b76-254

Bhatia, P., Ashwath, N., Senaratna, T., \& Midmore, D. (2004). Tissue culture studies of tomato (Lycopersicum esculentum). Plant Cell, Tiss. Org. Cult., 78, 1-21. http://dx.doi.org/10.1023/B:TICU.0000020430.08558.6e

Bodunde, J. G., Erinle, I. D., Eruotor, P. G., \& Amans, E. B., (1993). Recommendation for the release of four heat tolerant tomato varieties. Paper approved by the Professional and Academic board, IFAR, ABU, Zaria, Nigeria, p. 165.

Compton, M. E., \& Veilleux, R. E. (1991). Shoot, root and flower morphogenesis on tomato inflorescence explants. Plant Cell, Tiss. Org. Cult., 24, 223-231. http://dx.doi.org/10.1007/BF00033481

Costa, G. M., Nogueira, F. T .S., Otoni, W. C., \& Brommonschenkel, S. H. (2000). In-vitro regeneration of processing tomato (Lycopersicon esculentum Mill.) 'IPA-5' and IPA-6'. Ciencia e Agrotecnologia, 24, 671-678.

Davis, D. G., Breiland, K. A., Frear, D. S., \& Secor, G. A. (1994). Callus initiation and regeneration of tomato (Lycopersicon esculentum) cultivars with different sensitivities to metribuzin. Plant Growth Regulator Society of America Quarterly, 22, 65-73.

Evans, D. A. (1989). Somaclonal varaiation-genetic basis and breeding applications. Trends in Gen., 5, 46-50. http://dx.doi.org/10.1016/0168-9525(89)90021-8

FAOSTAT. (2011). Retrieved from http://faostat.fao.org/site/567/DesktopDefault.aspx?PageID=567\#ancor

Gunnay, A. L., \& Rao, P. S. (1980). In-vitro propagation of hybrid tomato plants (Lycopersicon esculentum L.) using hypocotyl and cotyledon explants. Annals of Botany, 45, 205-207.

Hamner, K. C., \& Maynard, L. A. (1942). Factors influencing the nutritional value of the tomato. A review of literature, U.S. Dept. of Agric. Misc. publication No. 52.

Hicks, G. S. (1994). Shoot induction and organogenesis in vitro: a developmental perspective. In Vitro Cell Dev Biol, 30, 10-15. 
Hobson, G., \& Davies, J. (1971). The Tomato. In A. Hulme (Ed.), The Biochemistry of Fruits and their Products (pp. 337-482). New York: Academic Press.

Jozef, G., Zuzana, L., \& Zuzana, J. (2004). Effect of growth regulators on shoot induction and plant regeneration in tomato (Lycopersicum esculentum Mill.). Biologia Bratislava, 59(3), 405-408.

Kalloo, G. (1991). Introduction. In G. Kalloo (Eds.), Monographs on Theoretical and Applied Genetics 14, Genetic Improvement of Tomato (pp. 1-9). Berlin, Heidelberg, New York: Springer-Verlag. http://dx.doi.org/10.1007/978-3-642-84275-7_1

Kartha, K. K., Gamborg, O. L., Shyluk, J. P., \& Constable, F. (1976). Morphogenic investigations on in vitro leaf culture of tomato (Lycopersicum esculentum Mill. cv. Starfire) and high frequency plant regeneration. Zeitschrift Fur Pflanzenphysiologie, 77, 292-301.

Kaul, M. (1991). Reproductive biology of tomato. In G. Kalloo (Ed.), Monographs on Theoretical and Applied Genetics 14, Genetic Improvement of Tomato (pp. 1-9). Berlin, Heidelberg, New York: Springer-Verlag. http://dx.doi.org/10.1007/978-3-642-84275-7_4

Locky, R. D. (1983). Callus formation and organogenesis by explants of six Lycopersicon species. Can. J. Bot., 61, 1072-1078. http://dx.doi.org/10.1139/b83-115

Mensuali-Sodi, A., Panizza, M., \& Togoni, F. (1995). Endogenous ethylene requirement for adventitious root induction and growth in tomato cotyledons and lavandin microcuttings in-vitro. Plant Growth Reg, 17, 205-212. http://dx.doi.org/10.1007/BF00024727

Mirghis, E., Mirghis, R., \& Lacatus, V. (1995). Analysis of tomato cultivars and hybrids for in vitro callus formation and regeneration. Acta Horticulturae, 412, 111-116.

Moorashige, T., \& Skoog, F. (1962). A revised medium for rapid growth and bioassays with tobacco tissue cultures. Physiol. Plant, 15, 473-497. http://dx.doi.org/10.1111/j.1399-3054.1962.tb08052.x

Ohki S., Bigot, C., \& Mouseau, J. (1978). Analyses of shoot forming capacity in vitro in two lines of tomato (Lycopersicon esculentum Mill.) and their hybrids. Plant Cell Physiology, 19, 27-42.

Olayide, S. O., Olatunbosun, D., Idusogie, E. O., \& Abiagom, J. D. (1972). A Quantitative analysis of food requirement, supplies and demand in Nigeria.1968-1985. p. 113.

Padmanabhan, V., Paddock, E. F., \& Sharp, W. R. (1974). Plantlet formation from Lycopersicum esculentum leaf callus. Canadian J. Bot., 52, 1429-1432. http://dx.doi.org/10.1139/b74-185

Plastira, V. A., \& Perdikaris, A. K. (1997). Effect of genotype and explants type on regeneration frequency of tomato in-vitro. Acta Horticulturae, 447, 231-234.

Pozueta-Romero, J., Houlne, G., Canas, L., Schantz, R., \& Chamarro, J. (2001). Enhanced regeneration of tomato and pepper seedling explants for Agrobacterium-mediated transformation. Plant Cell, Tissue and Organ Culture, 67(2), 173-180. http://dx.doi.org/10.1023/A:1011997926381

Sun, H., Uchii, S., Watanabe, S., \& Ezura, H. (2006). A highly efficient transformation protocol for Micro-Tom, a model cultivar for tomato functional genomics. Plant Cell Physiol., 47(3), 426-431. http://dx.doi.org/10.1093/pcp/pci251

Van der Vossen, H., \& Nono-Womdim, M. (2004). Lycopersicum esculentum Mill. In G. J. H. Grubben \& O. A. Denton (Eds.), Plant Resources of Tropical Africa 2. Vegetables (pp. 373-379). PROTA Foundation,Wageningen, Netherlands/Backhuys Publishers, Leiden, Netherlands/CTA, Wageningen, Netherlands.

Venkatachalam, P., Geetha, N., Priya, P., Rajaseger, G., \& Jayabalan, N. (2000). High frequency plantlet regeneration from hypocotyls explants of tomato (Lycopersicon esculentum Mill.) via organogenesis. Plant Cell, Biotechnology and Molecular Biology, 1, 95-100.

Villareal, R. L. (1980). Tomatoes in the Tropics (p. 174). Boulder, Colorado: Westview Press.

Zamir, D., Jones, R., \& Kedar, N. (1980). Anther culture of male-sterile tomato (Lycopersicon esculentum Mill.) mutants. Plant Science Letters, 17, 352-361. http://dx.doi.org/10.1016/0304-4211(80)90168-6 